\title{
Are current development programs realising the full potential of new agents?
}

\author{
Per Eystein Lønning*
}

\section{Introduction}

Following the seminal introduction of CMF (cyclophosphamide, methotrexate, and fluorouracil) for adjuvant breast cancer treatment more than three decades ago [1], the efficacy of adjuvant chemotherapy has gradually improved by the introduction of the anthracyclines [2] and, more recently, the taxanes [3]. However, while anthracycline-containing regimens have become standard treatment for oestrogen receptor (ER)-positive as well as ER-negative tumours, conflicting evidence has linked the use of adjuvant taxanes to improved outcome in patients with ER-positive tumours. This uncertainty has now, to a large extent, been resolved with the results from a recent study [4] revealing a benefit for ER-positive tumours with a high growth rate as evaluated by KI67 status, but no benefit for ER-positive tumours with a low KI67 score. These results indicate a way forward; while studies three decades ago centred on identifying prognostic factors in breast cancer, we are now starting to learn predictive factors identifying which tumours may achieve optimal benefit from defined therapeutic regimens [5]. This relates to established drug regimens and also to new experimental therapies in particular. While this is conventional wisdom with respect to targeted therapies, such as endocrine agents and antihuman epidermal growth factor receptor 2 (anti-HER-2) strategies, current data illustrate the need for predictive factors to enable optimal use of chemotherapy as well.

Realizing the need to identify predictive factors and, ideally, to understand the mechanisms causing drug resistance [6], translational research aiming at identifying such biological parameters should be part of most phase I to III trials [7]. Before discussing future perspectives and the implementation of novel drugs, a brief summary of the state of the art for predictive factors in breast cancer therapy is provided.

*Correspondence: per.lonning@helse-bergen.no

Section of Oncology, Institute of Medicine, University of Bergen, and Department of Oncology, Haukeland University Hospital, N-5021, Bergen, Norway

\section{Predictive factors in breast cancer treatment}

The topic of predictive factors in breast cancer treatment has recently been reviewed in detail by Lønning [8]; thus, a brief summary will be provided here.

While a slow tumour growth rate, as determined by KI67 expression, has been related to a good prognosis in patients on endocrine therapy [9], high Ki67 expression, as well as high histological grade, has been related to improved efficacy of chemotherapy, in particular a better chance of having a pathological complete response to primary systemic treatment [10-13]. With regards to other single parameters, TP53 mutations have been associated with poor response to anthracycline therapy $[14,15]$, but the sensitivity and specificity of these do not allow their implementation in routine clinical use. HER-2 amplification not only predicts efficacy of anti-HER-2 therapies but is associated with enhanced efficacy of anthracyclines at high doses [16,17], probably due to coamplification of topoisomerase II, an anthracycline target, in a subset of tumours $[18,19]$. The genes for both HER-2 and topoisomerase II are located in close proximity on chromosome 17 . Interestingly, recent data have suggested centromere amplification on this chromosome to be a better predictor of anthracycline sensitivity compared to amplification of either HER-2 or topoisomerase II [20].

Considering gene expression profiles, the OncotypeDX signature, initially developed as a prognostic signature in patients receiving adjuvant tamoxifen treatment [21], has been evaluated as a predictive factor with respect to chemotherapy efficacy. Notably, while a low score by this index revealed good prognosis among patients treated with tamoxifen but not chemotherapy, a high score signalled chemotherapy benefits with CMF [22] as well as anthracycline-containing treatment [23]. So far, the predictive value of this signature has been evaluated in patients harbouring ER-positive tumours exposed to tamoxifen; the potential predictive power of the signature with respect to the efficacy of CMF treatment in ERnegative tumours has not been addressed. Several of the genes included in the signature predict cellular proliferation rate; thus, it should be evaluated whether the information provided could be reflected to the same 
extent by simple cell cycle parameters like Ki67. As for other supervised signatures, while some have been associated with chemotherapy response, they lack the sensitivity and specificity required for clinical implementation (see references in [5]). Moreover, the specificity of supervised gene expression signatures with respect to which genes are included has been challenged [24].

As for the hierarchical gene expression signature developed by Perou and colleagues [25,26], tumour subclasses are not fully predictive of chemotherapy response in either the primary (neoadjuvant) or the adjuvant setting [27-29]. While TP53 mutations have a tendency to be present in tumours of the HER-2, luminal $\mathrm{B}$ and basal cell-like classes, they may also be detected among tumours belonging to the luminal A class, albeit at low incidence [26], underlining the correlation between different parameters but also tumour heterogeneity, probably the main reason why we have been unsuccessful in identifying accurate predictive factors.

\section{Do scientific aims need to be redefined?}

The findings summarized above reveal an emerging understanding of the mechanisms controlling tumour response to therapy. On the other hand, while some of these parameters are used clinically (such as HER-2 amplifications for anthracycline dose selection), we are still far from the goal of 'individualized medicine' - the selection of optimal therapy at an individual level based on predictive factors. To fully achieve such a goal will most probably require extension of our ambitions beyond identification of correlative predictive factors toward identification of the mechanisms causing drug resistance.

There may be several different entrances into this field. With regard to novel drugs in clinical trials, two important examples illustrate unexpected clinical observations that may lead translational research into a new area, and how new drugs may be designed based on molecular translational research identifying molecular defects in tumour subgroups.

The first example relates to novel drugs implemented for anti-HER-2 therapy. The tyrosine kinase inhibitor lapatinib inhibits HER-1 as well as HER-2 activity, and has been shown to have anti-tumour activity in tumours resistant to trastuzumab [30]. Surprisingly, among patients developing resistance to trastuzumab, lapatinib and trastuzumab given together improved progressionfree survival compared to lapatinib monotherapy [31]. Such observations define an ideal clinical setting from which tumour samples should be systematically collected and analyzed with the aim of identifying the molecular mechanisms dictating resistance versus sensitivity to these individual compounds.

The second approach - the design of therapeutic strategies from knowledge about particular gene defects in individual tumours - is illustrated by the development of poly ADP ribose polymerase (PARP) inhibitors for breast and ovarian cancers in patients harbouring $B R C A 1$ or BRCA2 mutations. BRCA1 and BRCA2 mutated tumours both have a defect in homologous DNA repair [32]. Thus, phase II studies have shown PARP inhibitors to have specific anti-tumour effects in breast as well as ovarian carcinomas with $B R C A 1$ and BRCA2 mutations [33]. Interestingly, PARP inhibitors were also found to enhance efficacy of chemotherapy in triple negative breast cancers not tested for $B R C A 1$ or $B R C A 2$ mutations [35]. Sixty to eighty percent of all triple negative breast cancers belong to the so-called basal cell-like class [36,37], and about $80 \%$ of all breast cancers arising in BRCA1 mutation carriers reveal a gene expression profile resembling basal cell-like tumours [26,38,39]. While only $10 \%$ of all basal-like breast cancers arise in BRCA1 mutation carriers [40], the similarity with respect to gene expression profile between spontaneous basal cell-like and BRCA1 mutated tumours has raised the question whether basal cell-like tumours may harbour other defects in the 'BRCA1' pathway [41]. However, the role of PARP inhibitors in basal cell-like tumours harbouring wild type $B R C A 1$ and $B R C A 2$ remains to be determined; in a recent study [42] none of 15 patients with advanced triple negative breast cancers responded to a PARP inhibitor administered as monotherapy. Currently, we lack an explanation for the seeming disparity between the studies by Gelmon and colleagues [42] and O'Shaughnessy and colleagues [35] with respect to the efficacy of PARP inhibition in triple negative breast cancer in general. There are several dissimilarities between the studies, one evaluating PARP inhibition as monotherapy, the other addressing the effect of adding a PARP inhibitor to a defined chemotherapy regimen. Finally, the studies used different PARP inhibitors, raising the issue of whether these compounds may express additional biological effects. Clearly, more data are needed to address this topic.

\section{The way forward}

So far, the development of individual predictive factors, as well as multigene-expression arrays, has had limited impact on therapy. While our aim should be to identify the functional mechanisms controlling drug resistance, the complexity of the issue should not be underestimated. The finding that nonsense CHEK2 mutations may substitute for TP53 mutations as a cause of anthracycline resistance [15] is consistent with Chk2 activating p53 in response to DNA damage, and suggests a pivotal role of this mechanism in effecting anthracycline-induced cell death. On the other hand, the p53 protein is subject to multiple modifications, including ubiquitinations, deacetylations and phosphorylations at multiple sites executed by different enzymes, and may directly interact 
with proteins like MDM2 and MDMX [43]. Thus, activation of different cellular processes is most likely due to multiple factors acting in concert and modulating the effects of each other. While substantial evidence suggests mutations affecting a limited number of genes may act as 'drivers' of tumour progression [44,45], we do not currently know whether similar phenomena relate to either primary or acquired drug resistance in vivo. Rapidly emerging technologies may allow such analysis to be applied to large sets of tumours at reasonable costs in the not too distant future [46].

Development of novel techniques for high-throughput sequencing opens new possibilities for exploring these issues. Thus, techniques are available for screening the whole genome for point mutations as well as indels or larger deletions/duplications. Thus, the first reported studies of this sort on breast carcinomas have revealed substantial inter-tumour diversity with respect to somatic alterations [47].

In conclusion, new knowledge and new technologies now suggest we should conduct clinical trials differently to what we have done over the past decades. The phase I to III trial 'ladder' remains; however, instead of confirming marginal benefits in repeated large phase III studies, we should concentrate on how we may use these new compounds optimally by exploring drug resistance. To do so, we not only need tumour tissue bank collections, but perhaps more importantly we need to design our clinical studies, whenever ethically justifiable, in a way that aims at exploring drug responsiveness in a manner that allows systematic comparisons between clinical response and biological parameters [48]. The examples provided by novel anti-HER-2 strategies as well as PARP inhibitors both illustrate ways forward.

\section{Abbreviations}

ER, oestrogen receptor; HER-2, human epidermal growth factor receptor 2; PARP, poly ADP ribose polymerase.

\section{Competing interests}

The author declares that they have no competing interests.

\section{Acknowledgements}

This article has been published as part of Breast Cancer Research Volume 12 Supplement 4, 2010: Controversies in Breast Cancer 2010. The full contents of the supplement are available online at http://breast-cancer-research.com/ supplements/12/S4

\section{Published: 20 December 2010}

\section{References}

1. Bonadonna G, Brusamolino E, Valagussa P, Rossi A, Brugnatelli L, Brambilla C, De Lena M, Tancini G, Bajetta E, Musumeci R, Veronesi U: Combination chemotherapy as an adjuvant treatment in operable breast cancer. N Engl J Med 1976, 294:405-410.

2. Early Breast Cancer Trialists' Collaborative Group: Effects of chemotherapy and hormonal therapy for early breast cancer on recurrence and 15-year survival: an overview of the randomised trials. Lancet 2005, 365:1687-1717.

3. Berry DA, Cirrincione C, Henderson IC, Citron ML, Budman DR, Goldstein LJ, Martino S, Perez EA, Muss HB, Norton L, Hudis C, Winer EP: Estrogen-receptor status and outcomes of modern chemotherapy for patients with nodepositive breast cancer. JAMA 2006, 295:1658-1667.

4. Penault-Llorca F, André F, Sagan C, Lacroix-Triki M, Denoux Y, Verriele V, Jacquemier J, Baranzelli MC, Bibeau F, Antoine M, Lagarde N, Martin AL, Asselain B, Roché H: Ki67 expression and docetaxel efficacy in patients with estrogen receptor-positive breast cancer. J Clin Oncol 2009, 27:2809-2815.

5. Lønning PE, Knappskog S, Staalesen V, Chrisanthar R, Lillehaug JR: Breast cancer prognostication and prediction in the postgenomic era. Ann Oncol 2007, 18:1293-1306.

6. Lønning PE: Genes causing inherited cancer as beacons identifying the mechanisms of chemoresistance. Trends Mol Med 2004, 10:113-118.

7. Lønning PE: Strength and weakness of phase I to IV trials, with an emphasis on translational aspects. Breast Cancer Res 2008, 10 (Suppl 4):S22.

8. Lønning PE: Molecular basis for therapy resistance. Mol Oncol 2010, 4:284-300.

9. Dowsett M, Smith IE, Ebbs SR, Dixon JM, Skene A, A'Hern R, Salter J, Detre S, Hills M, Walsh G; IMPACT Trialists Group: Prognostic value of Ki67 expression after short-term presurgical endocrine therapy for primary breast cancer. J Natl Cancer Inst 2007, 99:167-170.

10. Fisher E, Wang J, Bryant J, Fisher B, Mamounas E, Wolmark N: Pathobiology of preoperative chemotherapy. Cancer 2002, 95:681-695.

11. Hess KR, Anderson K, Symmans WF, Valero V, Ibrahim N, Mejia JA, Booser D, Theriault RL, Buzdar AU, Dempsey PJ, Rouzier R, Sneige N, Ross JS, Vidaurre T, Gómez HL, Hortobagyi GN, Pusztai L: Pharmacogenomic predictor of sensitivity to preoperative chemotherapy with paclitaxel and fluorouracil doxorubicin, and cyclophosphamide in breast cancer. J Clin Oncol 2006, 24:4236-4244.

12. Kuerer HM, Newman LA, Smith TL, Ames FC, Hunt KK, Dhingra K, Theriault RL, Singh G, Binkley SM, Sneige N, Buchholz TA, Ross MI, McNeese MD, Buzdar AU, Hortobagyi GN, Singletary SE: Clinical course of breast cancer patients with complete pathologic primary tumor and axillary lymph node response to doxorubicin-based neoadjuvant chemotherapy. J Clin Oncol 1999, 17:460-449.

13. Vincent-Salomon A, Rousseau A, Jouve M, Beuzeboc P, Sigal-Zafrani B, Fréneaux P, Rosty C, Nos C, Campana F, Klijanienko J, Al Ghuzlan A, SastreGarau X; Breast Cancer Study Group: Proliferation markers predictive of the pathological response and disease outcome of patients with breast carcinomas treated by anthracycline-based preoperative chemotherapy. Eur J Cancer 2004, 40:1502-1508.

14. Geisler S, Lønning PE, Aas T, Johnsen H, Fluge O, Haugen DF, Lillehaug JR, Akslen LA, Børresen-Dale AL: Influence of TP53 gene alterations and c-erbB-2 expression on the response to treatment with doxorubicin in locally advanced breast cancer. Cancer Res 2001, 61:2505-2512.

15. Chrisanthar R, Knappskog S, Løkkevik E, Anker G, Østenstad B, Lundgren S, Berge EO, Risberg T, Mjaaland I, Maehle L, Engebretsen LF, Lillehaug JR, Lønning PE: CHEK2 mutations affecting kinase activity together with mutations in the TP53 indicate a functional pathway associated with resistance to epirubicin in primary breast cancer. PLoS One 2008, 3:e3062.

16. Muss HB, Thor AD, Berry DA, Kute T, Liu ET, Koerner F, Cirrincione CT, Budman DR, Wood WC, Barcos M, et al:: C-erB-2 expression and response to adjuvant therapy in women with node-positive early breast cancer. N Engl J Med 1994, 330:1260-1266.

17. Petit T, Borel C, Ghnassia JP, Rodier JF, Escande A, Mors R, Haegelé P: Chemotherapy response of breast cancer depends on HER-status and antracycline dose intensity in the neoadjuvant setting. Clin Cancer Res 2001, 7:1577-1581.

18. Knoop AS, Knudsen H, Balslev E, Rasmussen BB, Overgaard J, Nielsen KV, Schonau A, Gunnarsdóttir K, Olsen KE, Mouridsen H, Ejlertsen B; Danish Breast Cancer Cooperative Group: Retrospective analysis of topoisomerase lla amplifications and deletions as predictive markers in primary breast cancer patients randomly assigned to cyclophosphamide, methotrexate, and fluorouracil or cyclophosphamide, epirubicin, and fluorouracil: Danish Breast Cancer Cooperative Group. J Clin Oncol 2005, 23:7483-7490.

19. Scandinavian Breast Group Trial 9401, Tanner M, Isola J, Wiklund T, Erikstein B, Kellokumpu-Lehtinen P, Malmström P, Wilking N, Nilsson J, Bergh J: Topoisomerase II alpha gene amplification predicts favorable treatment response to tailored and dose-escalated anthracycline-based adjuvant chemotherapy in HER-2/neu-amplified breast cancer: Scandinavian Breast Group Trial 9401. J Clin Oncol 2006, 24:2428-2436.

20. Bartlett JM, Munro AF, Dunn JA, MCConkey C, Jordan S, Twelves CJ, Cameron DA, Thomas J, Campbell FM, Rea DW, Provenzano E, Caldas C, Pharoah P, Hiller 
L, Earl H, Poole CJ: Predictive markers of anthracycline benefit: a prospectively planned analysis of the UK National Epirubicin Adjuvant Trial (NEAT/BR9601). Lancet Oncol 2010, 11:266-274.

21. Paik S, Shak S, Tang G, Kim C, Baker J, Cronin M, Baehner FL, Walker MG, Watson D, ParkT, Hiller W, Fisher ER, Wickerham DL, Bryant J, Wolmark N: A multigene assay to predict recurrence of tamoxifen-treated, nodenegative breast cancer. N Engl J Med 2004, 351:2817-2826.

22. Paik S, Tang G, Shak S, Kim C, Baker J, Kim W, Cronin M, Baehner FL, Watson D, Bryant J, Costantino JP, Geyer CE Jr, Wickerham DL, Wolmark N: Gene expression and benefit of chemotherapy in women with node-negative, estrogen receptor-positive breast cancer. J Clin Oncol 2006, 24:3726-3734.

23. Albain KS, Barlow WE, Shak S, Hortobagyi GN, Livingston RB, Yeh IT, Ravdin P, Bugarini R, Baehner FL, Davidson NE, Sledge GW, Winer EP, Hudis C, Ingle JN, Perez EA, Pritchard Kl, Shepherd L, Gralow JR, Yoshizawa C, Allred DC, Osborne CK, Hayes DF; Breast Cancer Intergroup of North America: Prognostic and predictive value of the 21-gene recurrence score assay in postmenopausal women with node-positive, oestrogen-receptor-positive breast cancer on chemotherapy: a retrospective analysis of a randomised trial. Lancet Oncol 2010, 11:55-65.

24. Ein-Dor L, Kela I, Getz G, Givol D, Domany E: Outcome signature genes in breast cancer: is there a unique set? Bioinformatics 2005, 21:171-178.

25. Perou CM, Sørlie T, Eisen MB, van de Rijn M, Jeffrey SS, Rees CA, Pollack JR, Ross DT, Johnsen H, Akslen LA, Fluge O, Pergamenschikov A, Williams C, Zhu SX, Lønning PE, Børresen-Dale AL, Brown PO, Botstein D: Molecular portraits of human breast tumours. Nature 2000, 406:747-752.

26. Sørlie T, Perou CM, Tibshirani R, Aas T, Geisler S, Johnsen H, Hastie T, Eisen MB, van de Rijn M, Jeffrey SS, Thorsen T, Quist H, Matese JC, Brown PO, Botstein D, Eystein Lønning P, Børresen-Dale AL: Gene expression patterns of breast carcinomas distinguish tumor subclasses with clinical implications. Proc Nat Acad SciU S A 2001, 98:10869-10874.

27. Sørlie T, Perou CM, Fan C, Geisler S, Aas T, Tibshirani R, Nobel A, Hastie T, Anker G, Akslen LA, Brown PO, Botstein D, Børresen-Dale A-L, Lønning PE: Differential sensitivity to doxorubicin and mitomycin among breast cancers belonging to the intrinsic subtypes identified by gene expression profiling. Mol Cancer Ther 2006, 5:2914-2918.

28. Rouzier R, Perou CM, Symmans WF, Ibrahim N, Cristofanilli M, Anderson K, Hess KR, Stec J, Ayers M, Wagner P, Morandi P, Fan C, Rabiul I, Ross JS, Hortobagyi GN, Pusztai L: Breast cancer molecular subtypes respond differently to preoperative chemotherapy. Clin Cancer Res 2005, 11:5678-5685.

29. Hugh J, Hanson J, Cheang MC, Nielsen TO, Perou CM, Dumontet C, Reed J, Krajewska M, Treilleux I, Rupin M, Magherini E, Mackey J, Martin M, Vogel C: Breast cancer subtypes and response to docetaxel in node-positive breast cancer: use of an immunohistochemical definition in the BCIRG 001 trial. J Clin Oncol 2009, 27:1 168-1176.

30. Blackwell KL, Pegram MD, Tan-Chiu E, Schwartzberg LS, Arbushites MC, Maltzman JD, Forster JK, Rubin SD, Stein SH, Burstein HJ: Single-agent lapatinib for HER2-overexpressing advanced or metastatic breast cancer that progressed on first- or second-line trastuzumab-containing regimens. Ann Oncol 2009, 20:1026-1031.

31. O'Shaugnessy J, Blackwell KL, Burstein H, Storniolo AM, Sledge G, Baselga J, Koehler M, Laabs S, Florance A, Roychowdhury D: A randomized study of lapatinib alone or in combination with trastuzumab in heavily pretreated HER2+ metastatic breast cancer progressing on trastuzumab therapy. J Clin Oncol 2008, 26(Suppl):abstract 1015

32. Martin SA, Lord CJ, Ashworth A: DNA repair deficiency as a therapeutic target in cancer. Curr Opin Genet Dev 2008, 18:80-86.

33. Tutt A, Robson M, J.E. G, Domchek S, Audeh MW, Weitzel JN, Friedlander M, Carmichael J: Phase II trial of the oral PARP inhibitor olaparib in BRCAdeficient advanced breast cancer. J Clin Oncol 2009, 27(18S):abstract CRA501.

34. Audeh MW, Penson RT, Friedlander ML, Powell B, Bell-McGuinn KM, Scott CG, Weitzel JN, Carmichael J, Tutt A: Phase II trial of the oral PARP inhibitor olaparib (AZD2281) in BRCA-deficient advanced ovarian cancer. J Clin Oncol 2009, 27(15S):abstract 5500.
35. O'Shaugnessy J, Osborne C, Pippen J, Yoffe M, Patt D, Monaghan G, Rocha C, Ossovskaya V, Sherman B, Bradley C: Efficacy of BSI-201, a poly (ADP-ribose) polymerase-1 (PARP1) inhibitor, in combination with gemcitabine/ carboplatin $(G / C)$ in patients with metastatic triple-negative breast cancer (TNBC): Results of a randomized phase II trial. J Clin Oncol 2009, 27(18S):abstract 3.

36. Rakha EA, Elsheikh SE, Aleskandarany MA, Habashi HO, Green AR, Powe DG, El-Sayed ME, Benhasouna A, Brunet JS, Akslen LA, Evans AJ, Blamey R, ReisFilho JS, Foulkes WD, Ellis IO: Triple-negative breast cancer: distinguishing between basal and nonbasal subtypes. Clin Cancer Res 2009, 15:2302-2310.

37. Cheang MC, Voduc D, Bajdik C, Leung S, McKinney S, Chia SK, Perou CM, Nielsen TO: Basal-like breast cancer defined by five biomarkers has superior prognostic value then triple-negative phenotype. Clin Cancer Res 2008, 14:1368-1376.

38. Hedenfalk I, Duggan D, Chen $Y$, Radmacher M, Bittner M, Simon R, Meltzer $P$, Gusterson B, Esteller M, Kallioniemi OP, Wilfond B, Borg A, Trent J, Raffeld M, Yakhini Z, Ben-Dor A, Dougherty E, Kononen J, Bubendorf L, Fehrle W, Pittaluga S, Gruvberger S, Loman N, Johannsson O, Olsson H, Sauter G: Gene-expression profiles in hereditary breast cancer. N Engl I Med 2001, 344:539-548.

39. Carey LA: Targeted chemotherapy? Platinum in BRCA1-dysfunctional breast cancer. J Clin Oncol 2010, 28:361-363.

40. Young SR, Pilarski RT, Donenberg T, Shapiro C, Hammond LS, Miller J, Brooks KA, Cohen S, Tenenholz B, Desai D, Zandvakili I, Royer R, Li S, Narod SA: The prevalence of BRCA1 mutations among young women with triple-negative breast cancer. BMC Cancer 2009, 9:86.

41. Turner NC, Reis-Filho JS, Russell AM, Springall RJ, Ryder K, Steele D, Savage K, Gillett CE, Schmitt FC, Ashworth A, Tutt AN: BRCA1 dysfunction in sporadic basal-like breast cancer. Oncogene 2007, 26:2126-2132.

42. Gelmon KA, Hirte HW, Robidoux A, Tonkin KS, Tischkowitz MD, Swenerton K, Huntsman D, Carmichael J, Macpherson E, Oza AM: Can we define tumors that will respond to PARP inhibitors? A phase II correlative study of olaparib in advanced serous ovarian cancer and triple-negative breast cancer. J Clin Oncol 2010, 28 (15S):abstract 3002.

43. Toledo F, Wahl GM: Regulating the $\mathrm{p} 53$ pathway: in vitro hypotheses, in vivo veritas. Nat Rev Cancer 2006, 6:909-923.

44. Sjöblom T, Jones S, Wood LD, Parsons DW, Lin J, Barber TD, Mandelker D, Leary RJ, Ptak J, Silliman N, Szabo S, Buckhaults P, Farrell C, Meeh P, Markowitz SD, Willis J, Dawson D, Willson JK, Gazdar AF, Hartigan J, Wu L, Liu C, Parmigiani G, Park BH, Bachman KE, Papadopoulos N, Vogelstein B, Kinzler KW, Velculescu VE: The consensus coding sequences of human breast and colorectal cancers. Science 2006, 314:268-274.

45. Greenman C, Stephens P, Smith R, Dalgliesh GL, Hunter C, Bignell G, Davies H, Teague J, Butler A, Stevens C, Edkins S, O'Meara S, Vastrik I, Schmidt EE, Avis T, Barthorpe S, Bhamra G, Buck G, Choudhury B, Clements J, Cole J, Dicks E, Forbes S, Gray K, Halliday K, Harrison R, Hills K, Hinton J, Jenkinson A, Jones D, Menzies $A$, et al:. Patterns of somatic mutation in human cancer genomes. Nature 2007, 446:153-158.

46. Stratton MR, Campbell PJ, Futreal PA: The cancer genome. Nature 2009, 458:719-724.

47. Stephens PJ, McBride DJ, Lin ML, Varela I, Pleasance ED, Simpson JT, Stebbings LA, Leroy C, Edkins S, Mudie LJ, Greenman CD, Jia M, Latimer C, Teague JW, Lau KW, Burton J, Quail MA, Swerdlow H, Churcher C, Natrajan R, Sieuwerts AM, Martens JW, Silver DP, Langerød A, Russnes HE, Foekens JA, Reis-Filho JS, van't Veer L, Richardson AL, Børresen-Dale AL, et al.: Complex landscapes of somatic rearrangement in human breast cancer genomes. Nature 2009, 462:1005-1010.

48. Lønning P: Study of suboptimum treatment response: lessons from breast cancer. Lancet Oncol 2003, 4:177-185.

\section{doi:10.1186/bcr2752}

Cite this article as: Lønning PE: Are current development programs realising the full potential of new agents? Breast Cancer Research 2010, 12(Suppl 4):S23. 